Review

\title{
PROGNOSTIC FACTORS OF CHILDHOOD ACUTE LYMPHOBLASTIC LEUKEMIA
}

\author{
Aleksandra Jovanovska ${ }^{1}$, Kata Martinova ${ }^{1}$ \\ 1 University Clinic for Children's Disease, Ss. Cyril and Methodius University in Skopje, Faculty of Medicine, \\ Republic of North Macedonia
}

Citation: Jovanovska A, Martinova K. Prognostic factors of childhood acute lymphoblastic leukemia -review of literature. Arch Pub Health 2021; 13 (1). doi.org/10.3889/aph.2021.5732

Key words: acute lymphoblastic leukemia, children, prognostic factors, minimal residual disease. survival.

*Correspondence: Aleksandra Jovanovska. University Clinic for Children's Disease, Skopje, Republic of North Macedonia E-mail: jovanovska.a@gmail.com Received: 10-Jan-2021; Revised: 28-Feb-2021; Accepted: 3-Mar-2021; Published: 10-Mar-2021

Copyright: 2021. Aleksandra Jovanovska, Kata Martinova. This is an open-access article distribut ed under the terms of the Creative Commons At tribution License, which permits unrestricted use, distribution, and reproduction in any medium, provided the original author(s) and source are credited Competing Interests: The author have declared that no competing interests

Преглед на литература

\begin{abstract}
The treatment outcome of acute lymphoblastic leukemia (ALL)has remarkably improved over the recent decades, leading to a 5-year overall survival rate up to $90 \%$. This impressive achievement is mainly due to the use of effective multi-agent chemotherapy regimens and the precise stratification of patients into risk groups based on well defined prognostic factors including the clinical features that are present at diagnosis, biologic and genetic features of leukemia cells, and early response to treatment. Patients classified as low risk are treated with less intensive therapy, whereas more aggressive regimens are reserved for those with high-risk features. Currently, minimal residual disease (MRD) is the most important and independent predictor of treatment outcome. This review will describe the clinical, biological, and responsebased features and current evidence supporting their clinical application in childhood ALL.
\end{abstract}

\section{ПРОГНОСТИЧК И ФАКТОРИ КАЈ ДЕТСКАТА АКУТНА ЛИМФОБЛАСТНА ЛЕУКЕМИЈА}

\author{
Александра Јовановска무, Ката Мартинова ${ }^{1}$

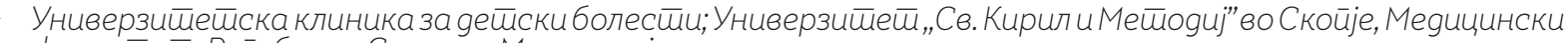 \\ факулиеиеи, Рейублика Северна Макеgонија
}

Цитирање: Јовановска А, Мартинова К. Прогностички фактори кај детската акутна лимфобластна леукемија-преглед на литература. Арх J Здравје 2021;13(1)

doi.org/10.3889/aph.2021.5732

Клучни зборови: акутна лимфобластна ле укемија, деца, прогностички фактори, минимална резидуална болест, преживување .

*Кореспонденција: Александра Јовановска, Универзитеска клиника за детски болести Скопје, Република Северна Македонија. E-mail: jovanovska.a@gmail.com

Примено: 10-јан-2021; Ревидирано: 28-фев-2021; Прифатено: 3-мар-2021; Објавено: 10-мар-2021

Печатарски права: ${ }^{\circledR 2021 ~ А л е к с а н д р а ~ Ј о в а н о в-~}$ ска, Ката Мартинова. Оваа статија е со отворен пристап дистрибуирана под условите на нелокализирана лиценца, која овозможува неограничен употреб дистрибуција и репродуциј нич бил уо со

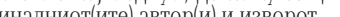
гиналниот(ите) автор(и) и изворот.

Конкурентски интереси: Авторот изјавува дека нема конкурентски интереси.

\section{Извадок}

Во последните неколку декади е остварен значаен напредок во терапискиот исход кај детската акутна лимфобластна леукемија (АЛЛ), што резултира со денешно 5-годишно вкүпно преживување кое достигнува до 90\%. Овој импресивен успех се должи на примената на ефикасни, комбинирани хемотераписки режими и прецизна стратификација на пациентите во ризични групи според добро дефинирани прогностички фактори кои ги вклучуваат клиничките карактеристики присутни при дијагнозата, биолошките и генетските карактеристики на леукемиските клетки и раниот одговор на терапија. Пациентите кои се класифицираат во прогностичка група со низок ризик се третираат со помалку интензивна терапија, додека за тие со високо-ризични карактеристики се применуваат поагресивни режими. Минималната резидуална болест (МРБ) во моментов претставува најважен и независен предиктор на терапискиот исход. Во овој ревијален труд се опишани клиничките, биолошките карактеристики и раниот одговор на терапија како и актуелните сознанија кои ја поддржуваат нивната клиничка примена кај детската АЛЛ. 


\section{Вовед}

Извонредниот напредок во третманот на детската акутна лимфобластна леукемија (АЛЛ) во последните неколку декади претставува еден од најголемите успеси во модерната медицина. Од речиси униформно фатална болест во 60-тите години на минатиот век, со развојот на ефикасни тераписки протоколи и прецизна стратификација на пациентите во ризични групи според добро дефинирани прогностички фактори, денешната стапка на 5-годишно вкупно преживување во голем број развиени земји низ светот достигнува до 90\% (табела 1). ${ }^{1-7}$ Сепак, прогнозата кај одредени подгрупи на детската АЛЛ е се́ уштесериозна, и тука се вклучуваат пациентитесо релапси, ${ }^{8}$ леукемијата во доенечка возраст ${ }^{9}$ и одредени поттипови на АЛЛ поврзани со специфични,високо-ризични генетски абнормалности ${ }^{10-12}$ за кои е потребен понатамошен напредок.

Во денешните педијатриски протоколи интензитетот на хемотерапијата се адаптира според проценетиот прогностички ризик чија цел е да се намали токсичноста кај пациентите со низок ризик, а да се обезбеди соодветна, поагресивна терапија кај тие со висок ризик. За прецизно дефинирање на ризичните групи се користат повеќе добро етаблирани прогностички фактори коиќе бидат опишани во овој ревијален труд, а ги вклучуваат клиничките карактеристики на пациентите при дијагнозата, биолошките и генетските карактеристики на леукемиските бласти и раниот одговор на терапија.

\section{Материјал и методи}

За евалуација на значењето и примената на прогностичките фактори во дефинирање на ризичните групи кај детската АЛЛ беше направен дескриптивен преглед на литературата достапна во медицинската база на податоци MEDLINE/PubMed. Bo прегледот беа вклучени клинички студии во кои се евалуира прогностичкото влијание на возраста, иницијалниот број на леукоцитите, ЦНС статусот, имунофенотипот, генетските карактеристики на леукемиските бласти и раниот одговор на терапија кај педијатриски пациенти со прекурсорна Б и Т-клеточна АЛЛ. Беа собирани податоци за методите за детекција на минималната резидуална болест (МРБ). Беше направен и преглед на клинички студии публицирани од светските лидерски студиски групи во кои се евалуира клиничкото значење на МРБ кај детската АЛЛ. Влијанието на сите ризик фактори врз прогнозата беше детерминирано преку стапка на вкупно преживување, преживување без настан и ризик за релапс. За пребарување на релевантна литература се користеа следните клучни зборови: акутна лимфобластна леукемија, деца, прогностички фактори, минимална резидуална болест, преживување.

\section{Резултати}

\section{Возраст и иницијален број на ле- укоцити}

Возраста при дијагнозата и иницијалниот број на леукоцитите се уште опстојуваат како фактори со предиктивно значење врз прогнозата. Според Националниот институт за канцер (NCI), тие се користат 
како критериум за стратификација на пациентите во групи со „стандарден ризик” (возраст 1 до 9,9 години и иницијален број на леукоцити $<50$ $\mathrm{x} 109 / \mathrm{L}$ ) и „Висок ризик” (возраст $\geq 10$ години и/или иницијален број на леукоцити $\geq 50 \times 109 / \mathrm{L})$, и во нив се опфатени околу $2 / 3$ и $1 / 3$, респективно од сите случаи со прекурсорна Бклеточна АЛЛ ${ }^{13}$. Децата на возраст од 1 до 10 години имаат значајно подобро преживување во споредба со постари деца, адолесценти и доенчиња $^{14}$ и ова би можело барем делумно да се објасни со високата фреквенција на поволни генетски карактеристики на лимфобластите во оваа возрасна група како присуството на хипердиплоидија и ген- ската фузија ETV6-RUNX1. ${ }^{4,15}$ Децата под 1 година се посебна подгрупа на пациенти кои се́ уште имаат неповолна прогноза лоша за доенчиња co MLL генски реаранжмани кои се под 6 месечна возраст или имаат екстремно висок иницијален број на леукоцити ( $\left.\geq 300 \times 10^{9} / \mathrm{L}\right) .{ }^{9}$ И во сегашната ера на нови биомаркери и стратификација на пациентите според минималната резидуална болест, иницијалниот број на леукоцитите се́ уште опстојува како независен предиктор на терапискиот исход. ${ }^{16,17}$ Возраста и иницијалниот број на леукоцитите имаат помало предиктивно значење кај Т-клеточната АЛЛ. ${ }^{18,19}$

Табела 1: Тераписки резултати од селектирани студиски групи

\begin{tabular}{|l|c|c|c|c|c|c|}
\hline Студиска група & $\begin{array}{c}\text { Времетраење } \\
\text { на студијата } \\
\text { (години) }\end{array}$ & $\begin{array}{c}\text { Број на } \\
\text { пациенти }\end{array}$ & Возраст & 5-годишен OS & $\begin{array}{c}\text { 5-годишен } \\
\text { ЕFS }\end{array}$ & Реф. \\
\hline AIEOP-BFM 2000 & $2000-2006$ & 4839 & $1-17$ & $91,9 \pm 0,4$ & $81,4 \pm 0,4$ & 1 \\
\hline MRC UKALL 2003 & $2003-2011$ & 3126 & $1-25$ & $91,6 \pm 1,2$ & $87,3 \pm 1,4$ & 2 \\
\hline DCOGALL10 & $2004-2012$ & 778 & $1-18$ & $91,9 \pm 1,0$ & $87 \pm 1,2$ & 3 \\
\hline $\begin{array}{l}\text { EORTC CLG } \\
\text { 58951 }\end{array}$ & $1998-2008$ & 1947 & $1-18$ & $89,7 \pm 0,7$ & $82,6 \pm 0,9$ & 4 \\
\hline COG & $2000-2005$ & 7153 & $0-21$ & $90,4 \pm 0,5$ & $/$ & 5 \\
\hline SJCRH XV & $2000-2007$ & 498 & $1-18$ & $93,5 \pm 1,9$ & $87,3 \pm 2,9$ & 6 \\
\hline DFCI 05-001 & $2005-2010$ & 551 & $1-18$ & 91 & 85 & 7 \\
\hline
\end{tabular}

Кратенки (англиски):OS, overall survival; EFS, event-free survival; AIEOP, Associazione Italiana di Ematologia Pediatrica Group; BFM, Berlin-Frankfurt-Münster;MRC UKALL, Medical Research Council United Kingdom acute lymphoblastic leukemia;DCOG, Dutch Children's Oncology Group;EORTC - CLG, European Organisation for Research and Treatment of Cancer - Children Leukemia Group;COG, Children's Oncology Group;SJCRH, St. Jude Children's Research Hospital;DFCI, Dana-Farber Cancer Institute consortium;IC-BFM, Intercontinental-BFM.

\section{Инфилтрација на ЦНС}

При дијагнозата, кај одредени суппопулации на пациенти како доенчиња и деца со Т-клеточна АЛЛ се забележува повисока инциденција на ЦНС леукемија. ${ }^{14}$ Пациентите кои имаат нетрауматска дијагностичка лумбална пункција, според бројот на леукоцитите $/ \mu \mathrm{L}$ и присуството или отсуството на бласти во церебро-спиналната течност (ЦСТ) на ци- 
тоспин препарат стандардно се класифицираат во една од следните три категории: ЦНС 1: отсуство на бласти во ЦСТ; ЦНС 2: присуство на бласти во ЦСТ која содржи $<5$ леукоцити/ $\mu \mathrm{L}$; ЦНС 3: во ЦСТ има $\geq 5$ леукоци$\mathrm{Tu} / \mu \mathrm{L}$ и се идентифицираат бласти или се детектира присуство на церебрална маса и/или парализа на кранијалните нерви. ЦНС статусот покажува корелација со прогнозата. Пациентите со ЦНС леукемија (ЦНС 3 статус) имаат зголемен ризик за развој на изолирани ЦНС релапси, и затоа во многу тераписки протоколи се кандидати за кранијална ирадијација. ${ }^{20}$ Сепак, некои студиски групи во контекст на сегашната ефективна системска и дополнителна интратекална хемотерапијаја елиминираат кранијалната ирадијација и исто така реферираат релативно низок кумулативен ризик за изолирани ЦНС релапси. ${ }^{21,22}$

\section{Имунофенотип}

Историски гледано, децата со Т-клеточна АЛЛ во изминатите декади имале помало преживување во споредба со оние со Б-клеточна АЛЛ, меѓутоа овие разлики со стратификација на пациентите во ризични групи според раниот одговор на терапија и примената на поинтензивни тераписки протоколи се надминати. ${ }^{5,23}$ Прогнозата е подобрена и кај пациентите со рана Т-клеточна прекурсорна АЛЛ (ЕТРALL) која во иницијалните клинички студии се препознава како високо ризична леукемија со бавен одговор на индукциска терапија и висока стапка на хематолошки релапси.24 Две неодамнешни клинички студииод лидерските студиски групи (COG и AIEOP-BFM) за овој поттипреферираат тераписки резулати кои се компа- рабилни со тие кај класичната Т-АЛЛ (5-годишно преживување без настан 87,0\% и 3-годишно преживување без настан 86,2\%, респективно). ${ }^{23,25}$

\section{Генетски карактеристики}

Со примена на стандардни цитогенетски и молекуларно-генетски анализи кај речиси 75\% од случаите на Б-АЛЛ се откриваат рекурентни хромозомски абнормалности како анеуплодија и специфични хромозомски реаранжмани кои резултираат со дерегулација на онкогените или со експресија на хибридни фузиски гени. Овие промени се присутни во сите леукемиски клетки и се од критично значење во механизмите на леукемогенезата. Нивната идентификација е од есенцијална важност за дефинирање на ризичните групи, а кај одредени генетски лезии и за примена на таргет терапија. И кај пациентите со Т-клеточна АЛЛ се идентифицирани мултипни генетски алтерации со можно прогностичко значење, меѓутоа студиските групи се́ уште не ги применуваат како стратификациски критериуми.

Генетски биомаркерки кои се асоцирани со одлична прогноза се $\mathrm{t}(12 ; 21)$ (ETV6-RUNX1) и хипердиплоидија (51-65 хромозоми). ${ }^{26}$ Пациентите со било која од овие хромозмски аберации имаат 5-годишно вкупно преживување кое надминува 90\%. Пет хромозмски абнормалности - MLL (KMT2A) реаранжманите, $\mathrm{t}(9 ; 22)(B C R-A B L 1), \mathrm{t}(17 ; 19)$ (TCF3-HLF), длабока хиподиплоидија (32-39 хромозми) и подгрупата на хиподиплоидија која се доближува до хаплоидија (24-31 хромозоми) се добро етаблирани прогностички биомаркери за високо-ризична АЛЛ во сите возрасни групи. ${ }^{27}$ 
Табела 2: Значајни прогностички фактори кај детската АЛЛ

\begin{tabular}{|c|c|}
\hline ПОВОЛНИ ПРОГНОСТИЧКИ ФАКТОРИ & НЕПОВОЛНИ ПРОГНОСТИЧКИ ФАКТОРИ \\
\hline Клинички карактеристики & Клинички карактеристики \\
\hline возраст 1-<10 години & возраст <1 годинаили $\geq 10$ години \\
\hline иницијален број на леукоцити <50 x109/L & иницијален број на леукоцити $\geq 50$ x109/L \\
\hline $\mathrm{NCl} \mathrm{SR}$ & $\mathrm{NCl} \mathrm{HR}$ \\
\hline ЦНС1 & ЦНСЗ \\
\hline Биолошки и генетски карактеристики & Биолошки и генетски карактеристики \\
\hline Б-клеточен имунофенотип & Т-клеточен имунофенотип (ETP-ALL) \\
\hline ETV6-RUNX1 & КМТ2А-реаранжмани \\
\hline хипердиплоидија (51-67хромозоми) & BCR-ABL1 \\
\hline \multirow[t]{5}{*}{ трисомија $+4,+10$} & TCF3-HLF \\
\hline & хиподиплоидна АЛЛ \\
\hline & iAMP21 \\
\hline & IKZF1 мутации или делеции \\
\hline & BCR-ABL1-like \\
\hline Ран одговор на терапија & Ран одговор на терапија \\
\hline Добар преднизонски одговор & Лош преднизонски одговор \\
\hline М1 морфологија на КС на ден 15 & М3 морфологија на КС на ден 15 \\
\hline $\begin{array}{c}\text { M1 морфологија на КС на крај на } \\
\text { индукциска терапија }\end{array}$ & $\begin{array}{c}\text { M2/M3 морфологија на КС на крај на } \\
\text { индукциска терапија }\end{array}$ \\
\hline МРБ во периферна крв <0,01\% наден 8 & МРБ во периферна крв $\geq 0,01 \%$ на ден 8 \\
\hline $\begin{array}{c}\text { МРБ во КС }<0,01 \% \text { на крај на индукциска } \\
\text { терапија }\end{array}$ & $\begin{array}{c}\text { МРБ во КС } \geq 0,1 \% \text { на крај на рана } \\
\text { консолидација }\end{array}$ \\
\hline
\end{tabular}

Кратенки:NCI-Национален институт за канцер; SR-стандарден ризик; HR-висок ризик; (дефинициите се приложени во текстот); ЦНС-централен нервен систем; рана Т-клеточна прекурсорна АЛЛ; М1: <5\% лимфобласти; М2: 5-25\% лимфобласти; М3>25\% лимфобласти при морфолошки преглед на коскената срцевина (КС); МРБ-минимална резидуална болест;

MLL (KMT2A)(11q23) реаранжманите се најчести кај децата во доенечка возраст и се асоцирани со неповолна прогноза.9Алогената трансплантација на хематопоетски матични клетки може да биде од корист само кај одредена, мала подгрупа на доенчиња со $M L L+$ АЛЛ кои имаат дополнителни неповолни клинички карактеристики како многу млада 
возраст, висок иницијален број на леукоцити и бавен одговор на терапија. ${ }^{28}$ Во клиничките студии од последните години се тестираат нови таргет терапии за оваа високо-агресивна леукемија. $M L L$ реаранжманите кај доенечката АЛЛ покажуваат асоцијација со прекумерна експресија на тирозин-киназа рецепторскиот ген FLT3, но примената на FLT3 инхибитори како lestaurtinib во комбинација со постиндукциска хемотерапија не се покажала како стратегија која резултира со подобро преживување. ${ }^{29}$

\section{BCR-ABL1 (Philadelphia}

[Ph] chromosome) - позитивната АЛЛ се јавува кај 2\% до 5\% од сите случаи на детската АЛЛ и иако историски се поврзува со неповолна прогноза, денес има значајно подобро преживување кое се должи на примена на таргетирана терапија со тирозин-киназни инхибитори. Комбинацијата на imatinibmesylatсо интензивна хемотерапијае добро толерирана тераписка стратегија кај детската АЛЛ од која резултира 5-годишно преживување кое достигнува до 70\%. ${ }^{30}$ Остварување на негативна МРБна крај на индукциска терапија покажува асоцијација со одлична прогноза. ${ }^{31}$

Хиподиплоидната АЛЛ се јавува кај 2 до 3\% од сите случаи на детската Б-АЛЛ и се карактеризира со различен мутациски профил. Пациентите со длабока хиподиплоидија (32 до 39 хромозоми) имаат генетски алтерации кои го инволвираат лимфоидниот транскрипциски фактор IKAROS (IKZF2) и многу често се носители на герминативни мутации вотумор-супресорскиот ген ТР53кои се конзистентни со синдромот наLi-Fraumeni. ${ }^{32}$ Кај подгрупата која се доближува до хаплоидија се детектираат активациски мутации во Ras-генот и алтерации во IKZFЗгенот. ${ }^{32}$ Прогнозата кај овој поттип на АЛЛ е значајно подобрена со имплементацијата на МРБ во стратегиите за тераписка стратификација. ${ }^{33}$

Генскиот транскрипт E2A-PBX1 $(\mathrm{t}(1 ; 19)(\mathrm{q} 23 ; \mathrm{p} 13.3))$ во контекст на денешните интензивни хемотераписки протоколи не претставува неповолен прогностички фактор, иако некои студии реферираат дека овој генотип го зголемува ризикот за развој на ЦНС релапси. ${ }^{34}$ Варијантата на $\mathrm{t}(1 ; 19)$, транслокацијата $\mathrm{t}(17 ; 19)$ (q23;p13)/TCF3-HLF е многу редок наод кај детската Б-АЛЛ $(<1 \%)$ и се поврзува со екстремно лоша прогноза. ${ }^{35}$

Комплексната интрахромозомска амплификација на 21-иот хромозом најчесто се јавува кај постари деца и покажува асоцијација со зголемен ризик за релапси, меѓутоа со примена на хемотераписки протоколи за високо-ризична АЛЛ некои студиски групи реферираат подобрено преживување. ${ }^{36,37}$

И покрај тоа што околу 25\% до 30\% од педијатриските пациенти со Б-АЛЛ на стандрадните генетски анализи се негативни за добро етаблираните дијагностички и прогностички биомаркери, со денешните технологии во молекуларната генетика, како на пример со секвенционирање на цел геном и егзом практично сите случаи на Б-АЛЛ може да бидат генетски класифицирани. Случаите без познати хромозомски алтерации се класифицираат како други типови на Б-АЛЛ. Околу 50\% од овие случаи имаат генски профил сличен на $B C R-A B L 1+$ АЛЛ, но немаат BCRABL1 транслокацијаи формираат 
посебна подгрупа означена како $B C R-A B L 1$-слична или $P h$-слична АЛЛ која е внесена во класификациската шема на СЗО ревидирана во 2016 година како нов ентитет на високо-ризична леукемија асоцирана со слаб одговор на индукциска терапија (резистенција на daunorubicinи L-asparaginasa) и неповолна прогноза. ${ }^{10,11,38}$ Преваленцијата на $B C R-A B L 1$-сличната АЛЛ се зголемува со возраста и варира од 10\% кај детската АЛЛ со стандарден ризик до 27\% кај адолесценти и млади адулти со Б-АЛЛ.39

Повеќе од 70\% од пациентите со овој поттип, слично на оние со BCR$A B L 1+$ АЛЛ имаат генетски алтерации кои ги инволвираат Б-лимфоидните транскрипциски фактори, особено вклчувајќи ги Ikaros гените (делеции на IKZF1). ${ }^{10,11}$ Кај речиси $50 \%$ од децата со BCR-ABL1-сличната АЛЛ се откриваат генски реаранжмани во цитокинскиот рецептор CRLF2 кои резултираат со прекумерна експресија на CRLF2 на површината на лимфоидните бласти и дополнително околу половина од овие случаи имаат конкомитантни активациски мутации во Janus kinasaгените JAK1 и ЈАK2 кои резултираат со активација на ЈAKSTAT сигналните патишта, промовирајќи преживување и пролиферација на Б-лимофидните клетки. ${ }^{39,40}$ Во повеќето студии CRLF2 реаранжманите, а особено во случаите со конкомитантна делеција на IKZF1 и активациски мүтации во JAK1 и JAK2 генитесе асоцирани со висока стапка на релапси и неповолна прогноза. ${ }^{40,41}$ Идентификацијата на овие абнормалности е важна затоа што пациентите со овој генски профил може да имаат корист од таргет терапија со JAK инхибитори (ruxolitinib).39 Друга подгрупакоја опфаќа околу $10 \%$ од сите случаи на BCR-ABL1-сличната АЛЛ се пациенти со генетски алтерации кои ги активираат JAK-STAT сигналните патишта вклучувајќи реаранжмани на JAK2 и EPOR гените и се исто така кандидати за терапија со JAK инхибитори. 39 Трета подгрупа која сочинува $15 \%$ до $20 \%$ од сите случаи на детската $B C R-A B L 1-$-слична АЛЛ се пациенти со реаранжмани во $A B L 1$-класа гените ( $A B L 1, A B L 2$, CSF1R и PDGFRB) кои реагираат на терапија со тирозин-киназни инхибитори како imatinib и dasatinib. ${ }^{39}$

\section{Ран одговор на терапија}

Прогностичкото значење на брзиот морфолошки клиренс на леукемиските бласти од периферната крв и коскената срцевина во иницијалните фази од хемотерапијата е потврдено во бројни клинички студии. ${ }^{42-44}$ Со декади, морфолошката проценка на раниот одговор на терапија се користи како главен стратификациски критериум за дефинирање на

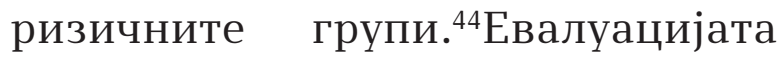
на преднизонскиот одговор која е воведена во 1983 година од страна на BFM (Berlin-Frankfurt-Münster) студиската група ${ }^{42}$ се́ уште опстојува како еден од најмоќните прогностички фактори кај детската АЛЛ. ${ }^{16}$ Пациентите со добар преднизонски одговор (<1x109/L леукемиски бласти во периферната крв по 7 дена терапија со преднизон и една интратекална апликација на метотрексат) имаат значајно подобро преживување во однос на ониесо лош преднизонски одговор (>1x109/L леукемиски бласти). ${ }^{44}$ 
Морфолошкиот преглед на коскената срцевина 15-от ден од индукциската терапија е исто така добро етаблиран прогностички фактор во BFM клиничките студии. ${ }^{45}$ Бавниот одговор на коскената срцевина во раните фази од индукциската хемотерапија корелира со неповолен клинички исход. ${ }^{45,46}$ Во клиничката студија ALL IC BFM 2002 раниот одговор на коскената срцевина е користен како еден од стратификациските критериуми за дефинирање на прогностичките групи. ${ }^{46}$

Пациентите кои нема да остварат морфолошка ремисија на крај на индукциска терапија се соисклучително лоша прогноза. Перзистенцијата на леукемиските бласти во коскената срцевина $(>5 \%)$ или во која било екстрамедуларна локализација по 4 до 6 недели индукциска терапија е редок, но сигнификантен настан кој се јавува кај 2\% до 3\% од сите пациенти и резултира со 10-годишно вкупно преживување до $30 \% .{ }^{47}$ Овие пациенти најчесто имаат високо ризични карактеристики при дијагнозата како постара возраст, висок иницијален број на леукоцити, Т-клеточен имунофенотип, $M L L$ - реаранжмани или $B C R-A B L+$ АЛЛ и се третираат со поинтензивна терапија вклучувајќи и алогена трансплантација на хематопоетски матични клетки во прва ремисија. ${ }^{47,48}$

\section{Минимална резидуална болест}

И покрај јасната идентификација на ризичните групи, цитоморфолошкиот преглед на коскената срцевина има ограничена сензитивност и специфичност, затоа што сепак сигнификантен број на пациенти кои ќе остварат комплетна морфолошка ремисија развиваат релапси како резултат на резидуални малигни клетки кои остануваат недетектирани со стандардните микроскопски техники. ${ }^{49}$ Во последните 2-3 декади повеќето студиски групи се фокусираат на детекција и квантификација на леукемиските клетки на субмикроскопско ниво или на така наречена минимална резидуална болест (МРБ), која во бројни клинички студии се идентификува како најрелевантен прогностички индикатор за детската АЛЛ. 2,3,6,16,17,50-55

Мерењето на МРБ во денешните тераписки протоколи претставува фундаментална алатка за проценка на раниот одговор на терапија и стратификација во ризични групи и тоа не само кај пациентите со de novo АЛЛ, туку и кај тие со релапси, како и пред и по фазите на алогена трансплантација на хематопоетски матични клетки. ${ }^{57}$ Количината на резидуална леукемија во текот на третманот се наоѓa во директна и сигнификантна релација со ризикот за развој на релапс. Според овој концепт пациентите со брз клиренс на МРБ на крај на индукциска терапија може успешно да бидат третирани со помалку токсични протоколи, ${ }^{3,54,56}$ за разлика од пациентите со високи нивоа на МРБ кои имаат неповолна прогноза и кај коиза подобрување на клиничкиот исход е потребна дополнителна постиндукциска интензификација. 2,3,16,21,55

Во клиничката пракса за одредување на МРБ се користат три стандардни методи: 1) мултипараметриска проточна цитометрија (MFC) со која се детектира аберантен леукемиски имунофенотип, 2) полимераза-верижна реакција-PCR амплификација на специфични клонотипски генски реаранжма- 
ни во имуноглобулинските (Ig) или во гените за Т - клеточниот рецептор (TCR) и 3) PCR амплификација на фузиски транскрипти, продукти на различни хромозомски транслокации.58 Овие методологии овозможуваат детекција на една леукемиска клетка во 10-4 (10 000) до 10-5 (100 000) нормални клетки, што претставува најмалку 100 пати поголема сензитивност во споредба со таа на конвенционалната оптичка микроскопија. Главните карактеристики на трите методи се сумирани во табела бр. 3.

\begin{tabular}{|c|c|c|c|}
\hline & $\begin{array}{l}\text { МУЛТИКОЛОРНА ПРО- } \\
\text { ТОЧНА ЦИТОМЕТРИЈА }\end{array}$ & RQ-PCR & RQ-PCR \\
\hline Таргет & $\begin{array}{c}\text { Леукемија-асоцирани } \\
\text { имунофенотипови }\end{array}$ & $\begin{array}{l}\mathrm{Ig} / \mathrm{TCR} \text { генски } \\
\text { реаранжмани }\end{array}$ & $\begin{array}{c}\text { Фузиски генски } \\
\text { транскрипти }\end{array}$ \\
\hline $\begin{array}{c}\text { Апликабил- } \\
\text { ност }\end{array}$ & $90 \%-95 \%$ & $90 \%-95 \%$ & $30 \%-40 \%$ \\
\hline Материјал & $\begin{array}{l}\text { клеточна суспензија } \\
\text { (периферна крв/КС) }\end{array}$ & $\begin{array}{c}\text { нуклеински киселини } \\
\text { (DNA) }\end{array}$ & $\begin{array}{c}\text { нуклеински киселини } \\
\text { (RNA/DNA) }\end{array}$ \\
\hline Сензитивност & $\begin{array}{c}\text { 3-4 колорна } \\
10^{-3}-10^{-4} \\
\text { 6-9 колорна } \\
10^{-4}-10^{-5} \\
\end{array}$ & $10^{-4}-10^{-5}$ & $10^{-4}-10^{-5}$ \\
\hline $\begin{array}{c}\text { Стабилност на } \\
\text { примерокот }\end{array}$ & $\begin{array}{c}\text { бара свежи вијабилни } \\
\text { клетки }\end{array}$ & $\begin{array}{c}\text { пролонгирана } \\
\text { стабилност }\end{array}$ & пролонгирана стабилност \\
\hline Предности & \begin{tabular}{|ll} 
- & апликабилна кај речиси \\
- & сите пациенти со АЛЛ \\
- & прецизна МРБ \\
- & квантификација \\
& иополнителни \\
& информации за \\
- & станните клетки \\
стардизирана
\end{tabular} & \begin{tabular}{|ll} 
- & висока сензитивност \\
висок степен на \\
стандардизација \\
добро етаблирана \\
стратификациска \\
алатка во различни \\
клинички протоколи \\
апликабилна \\
кај речиси сите \\
пациенти со АЛЛ
\end{tabular} & $\begin{array}{ll}\cdot & \text { висока сензитивност } \\
\text { стабилност на РCR } \\
\text { таргетите во текот на } \\
\text { третманот } \\
\text { брза } \\
\text { - } \quad \text { релативно евтина } \\
\text { апликабилна кај } \\
\text { одредени поттипови } \\
\text { на леукемија како } \\
\text { BCR-ABL U MLL-AF4 }\end{array}$ \\
\hline Недостатоци & 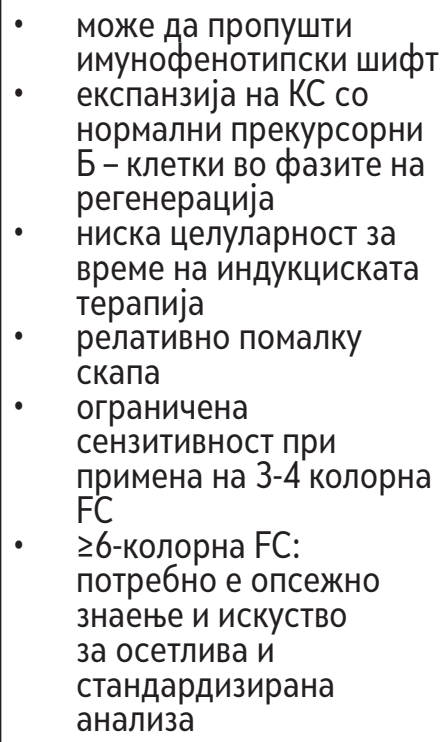 & $\begin{array}{ll}\text { - } & \text { може да пропушти } \\
& \text { нови Ig и ТСR генски } \\
\text { реаранжмани } \\
\text { - } \\
\text { бара многу време } \\
\text { за дизајнирање } \\
\text { на специфични } \\
\text { прајмери за } \\
\text { пациентот } \\
\text { потребно е опсежно } \\
\text { - } \\
\text { знаење и искуство } \\
\text { релативно поскапа }\end{array}$ & $\begin{array}{ll}\cdot & \text { ограничена } \\
\text { стандардизација } \\
\text { ограничена } \\
\text { апликабилност } \\
\text { (отсуство на таргети } \\
\text { кај > 50\%од случаите) } \\
\text { ризик од } \\
\text { контаминација }\end{array}$ \\
\hline
\end{tabular}

Кратенки: RQ-PCR квантитативнаполимераза верижна реакција во реално време; FC-проточна цитометрија, АЛЛ-акутна лимфобластна леукемија; МРБ-минимална резидуална болест; КС-коскена срцевина; 


\section{Клиничко значење на МРБ кај детската АЛЛ}

Детекцијата на МРБ во раните фази од третманот (ремисиска индукција и консолидација) има најмоќно прогностичко влијаниево сите досегашни публицирани клинички студии за детската АЛЛ.,2,3,6,16,17,50-56 Најчесто користена cutoff вредност од студиските групи за дефинирање на позитивен МРБ статус е 0,01\% (104), затоа што ова е типичен лимит за детекција на резидуални клетки со рутинска проточна цитометрија или со молекуларни техники и лимит кој има суверенозначење во дискриминација на пациентите со различен ризик за релапс на болеста.

Во раните клинички студии од детската истражувачка болница St. Jude (SJCRH), нивоата на МРБ $\geq 0,01 \%$ на ден 19 и 46, кои кореспондирале со средината и крајот на индукциската терапијасе покажале како најважен предиктивен фактор за релапси. ${ }^{50,51}$ МРБ била идентифицирана и како независен прогностичкифактор во однос на останатите клинички и генетски карактеристики. ${ }^{50}$ Клиничкото значење на имунолошката детекција на МРБ е дефинитивно потврдено во големата мултицентрична студија на Детската онколошка група (COG) во која биле евалуирани 2143 деца со прекурсорна Б-клеточна АЛЛ. ${ }^{53}$ Во студијата, МРБ на крај на индукциската терапија (ден 29) била утврдена како најмоќен предиктор на терапискиот исход кај детската Б-АЛЛ. Пациентите со негативна МРБ (n = 1588) на крај на индукциската терапија имале супериорно 5-годишно преживување без настан за разлика од оние со високи нивоа на МРБ $>1 \%$ (88\% наспроти $33 \%$, респективно). Во оваа клиничка студија е потврдено и предиктивното значење на МРБ во периферната крв 8-от ден од индукциската терапија. Пациентите со високи нивоа на МРБ во оваа временска точка (>1\%) имале релативно лоша прогноза, па дури и доколку оствареле негативна МРБ на крај на индукциска терапија. Стапката на 5-годишно преживување без настан за оваа популација на пациенти изнесувала 79\% наспроти 90\% за оние со ниски нивоа на МРБ ( $\leq 1 \%)$ 8-от ден од индукциската терапија.

Најголемата рандомизирана клиничка студија AIEOP-BFM 2000 го евалуирала прогностичкото значење на МРБ детерминирана со RTPCR кај 3184 деца со прекурсорна Б-клеточна АЛЛ во две временски точки - ден 33 и 78 од терапискиот протокол. ${ }^{16}$ Според молекуларниот одговор на коскената срцевина пациентите биле стратифицирани во 3 ризични групи: 1) група со стандадрен ризик (негативна МРБ $<0,01 \%$ на ден 33 и 78); 2) висок ризик (МРБ $>0,1 \%$ на ден 78) и 3) интермедијарен ризик (сите останати). Стапката на 5-годишно преживување без настан за пациентите со стандарден, интермедијарен и висок ризик изнесувала $92 \%, 77 \%$ и 50\%, респективно. Авторите заклучиле дека МРБ претставува најважен предиктивен фактор за релапси кај детската Б-АЛЛ, намалувајќи го значајно прогностичкото влијание на генетските фактори, преднизонскиот одговор и NCI ризичните групи.

Нивоата на МРБ одредени и порано, на пр. на ден 15 од индукциската терапија исто така имаат сигнификантно значење врз прогнозата кај детската АЛЛ. ${ }^{59,60}$ Во клиничката студија на AIEOP, 815 
педијатриски пациенти според одговорот на коскената срцевина на ден 15 евалуиран со проточна цитометрија биле класифицирани во три ризични групи. ${ }^{59}$ Пациентите со висок ризик (МРБ $\geq 10 \%)$ имале значајно повисока 5-годишна кумулативна инциденција на релапси која изнесувала $47,2 \%$ во однос на оние со интермедијарен (МРБ 0,1-<10\%) и стандарден ризик (МРБ $<0,1 \%)$ кај кои била опсервирана стапка на релапси од $17,5 \%$ и 7,5\%, респективно.

За разлика од Б-клеточната АЛЛ, динамиката на клиренсот на резидуалните леукемиски клетки кај Т-АЛЛ се одвива побавно. Истражувачите од клиничката студија AIEOP-BFM 2000 заклучиле дека позитивна МРБ по фазата на рана консолидација (ден 78) претставува најважен предиктор за релапси кај пациентите со Т-клеточна АЛЛ.55 Влијанието на МРБ статусот на ден 33 било ирелевантно за 48\% од пациентите кои оствариле негативна МРБ по фазата на рана консолидација. Оваа кохорта на пациенти имала одлична прогноза (7-годишна кумулативна инциденција на релапси од 8,5\%). За разлика од нив, пациентите со високо позитивна МРБ $(>0,1 \%)$ на ден 78 имале значајно полоша прогноза (7-годишна кумулативна инциденција на релапси од $44,7 \%)$.

\section{Заклучок}

Повеќе клинички и биолошки карактеристики кои ги вклучуваат возраста, иницијалниот број на леукоцитите, ЦНС статусот, имунофенотипот, присуството на генетски абнормалности и одговорот на иницијалната терапија имаат сигнификантно прогностичко влија- ние кај детската АЛЛ. Примената на овие прогностички фактори, а особено имплементацијата на МРБ во стратификацијата на пациентите во ризични групи резултира со денешно 5-годишно вкупно преживување кое достигнува до 90\%. Целта за наредните години е излекување и на пациентите кои имаат високоризична АЛЛ и се рефракторни на прво-линискиот третман или развиваат релапси преку понатамошна попрецизна стратификација и планирање на таргетирана, индивидуализирана терапија.

\section{Референци}

1. Moricke A, Zimmermann M, Valsecchi MG, et al. Dexamethasone vs prednisone in induction treatment of pediatric ALL: results of the randomized trial AIEOP-BFM ALL 2000. Blood 2016; 127(17): 2101-12.

2. Vora A, Goulden N, Mitchell C, et al. Augmented post-remission therapy for a minimal residual diseasedefined high-risk subgroup of children and young people with clinical standard-risk and intermediate-risk acute lymphoblastic leukaemia (UKALL 2003): a randomised controlled trial. Lancet Oncol 2014; 15(8): 809-18.

3. Pieters R, de Groot-Kruseman H, Van der Velden V, et al. Successful therapy reduction and intensification for childhood acute lymphoblastic leukemia based on minimal residual disease monitoring: Study ALL10 from the Dutch Childhood Oncology Group. Journal of Clinical Oncology 2016; 34(22): 2591-601.

4. Domenech C, Suciu S, De Moerloose B, et al. Dexamethasone $(6 \mathrm{mg} / \mathrm{m} 2 /$ day) and prednisolone $(60 \mathrm{mg} / \mathrm{m} 2 /$ 
day) were equally effective as induction therapy for childhood acute lymphoblastic leukemia in the EORTC CLG 58951 randomized trial. Haematologica 2014;99(7):1220-7

5. Hunger SP, Lu X, Devidas M, et al. Improved survival for children and adolescents with acute lymphoblastic leukemia between 1990 and 2005: a report from the Children's Oncology Group. J Clin Oncol 2012;30, 1663-1669.

6. Pui CH, Pei D, Coustan-Smith E, et al. Clinicalutility of sequential minimal residual disease measurements in the context of risk-based therapy in childhood acute lymphoblastic leukaemia: a prospective study. Lancet Oncol 2015;16(4):465-74.

7. Place AE, Stevenson KE, Vrooman LM, et al. Intravenous pegylated asparaginase versus intramuscular native Escherichia coli L-asparaginase in newly diagnosed childhood acute lymphoblastic leukaemia (DFCI 05-001): a randomised, openlabel phase 3 trial. Lancet Oncol 2015; 16(16): 1677-90.

8. Oskarsson T, Söderhäll S, J, et al. Relapsed childhood acute lymphoblastic leukemia in the Nordic countries: prognostic factors, treatment and outcome. Haematologica 2016; 101(1): 68-76.

9. Pieters R, Schrappe M, De Lorenzo $\mathrm{P}$, et al. A treatment protocol for infants younger than 1 year with acute lymphoblastic leukaemia (Interfant-99): An observational study and a multicentre randomised trial. Lancet 2007;370(9583):240-250.

10. Mullighan CG, Su X, Zhang J, et al. Deletion of IKZF1 and prognosis in acute lymphoblastic leukemia. N Engl J Med 2009; 360(5):470-80.
11. Den Boer ML, van Slegtenhorst M, De Menezes RX, et al. A subtype of childhood acute lymphoblastic leukaemia with poor treatment outcome: a genome-wide classification study. Lancet Oncol 2009; 10(2):125-34.

12. van der Veer A, Waanders E, Pieters R, et al. Independent prognostic value of BCR-ABL1-like signature and IKZF1 deletion, but not high CRLF2 expression in children with B-cell precursor ALL. Blood 2013;122(15):2622-9.

13. Smith M, Arthur D, Camitta B,et al. Uniform approach to risk classification and treatment assignment for children with acute lymphoblastic leukemia. J Clin Oncol 1996;14(1):18-24.

14. Moricke A, Zimmermann M, Reiter A, et al. Prognostic impact of age in children and adolescents with acute lymphoblastic leukemia: data from the trials ALL-BFM 86, 90, and 95. Klin Padiatr 2005;217(6):310-20.

15. Forestier E, Schmiegelow K. The incidence peaks of the childhood acute leukemias reflect specific cytogenetic aberrations. J Pediatr Hematol Oncol 2006;28(8):486-95.

16. ConterV,BartramCR,ValsecchiMG,et al. Molecular response to treatment redefines all prognostic factors in children and adolescents with B-cell precursor acute lymphoblastic leukemia: results in 3184 patients of the AIEOP-BFM ALL 2000 study. Blood 2010;115(16):3206-14.

17. Borowitz MJ, Wood BL,Devidas M, et al. Prognostic significance of minimal residual disease in high risk BALL: a report from Children's Oncology Group study AALL0232. Blood 2015;126(8):964-71.

18. Maloney KW, Shuster JJ, Murphy S, et al. Long-term results of treatment 
studies for childhood acute lymphoblastic leukemia: Pediatric Oncology Group studies from 1986-1994. Leukemia 2000; 14:2276.

19. Pullen J,Shuster JJ, Link M, et al. Significance of commonly used prognostic factors differs for children with $\mathrm{T}$ cell acute lymphocytic leukemia (ALL), as compared to those with B-precursor ALL. A Pediatric Oncology Group (POG) study. Leukemia 1999;13(11):1696-707.

20. PuiCH, Howard SC. Current management and challenges of malignant disease in the CNS in paediatric leukaemia Lancet Oncol 2008;9(3):257-68.

21. Pui CH, Campana D, Pei D, et al. Treating childhood acute lymphoblastic leukemia without cranial irradiation. N Engl J Med 2009;360(26):2730-41.

22. Veerman AJ, Kamps WA, van den Berg H, et al. Dexamethasone-based therapy for childhood acute lymphoblastic leukaemia: results of the prospective Dutch Childhood Oncology Group (DCOG) protocol ALL-9 (19972004). Lancet Oncol 2009;10:957-966.

23. Wood BL, Winter SS, Dunsmore KP, et al. T-Lymphoblastic Leukemia (TALL) shows excellent outcome, lack of significance of the early thymic precursor (ETP) immunophenotype, and validation of the prognostic value of end-induction minimal residual disease (MRD) in Children's Oncology Group (COG) Study AALL0434. Blood 2014;124(21):1.

24. Coustan-Smith E, Mullighan CG, Onciu M, et al. Early T-cell precursor leukaemia: a subtype of very highrisk acute lymphoblastic leukaemia. Lancet Oncol 2009; 10:147.

25. Conter V, Valsecchi MG, Buldini B, et al. Early T-cell precursor acute lymphoblastic leukaemia in children treated in AIEOP centres with AIEOP-BFM protocols: a retrospective analysis.Lancet Haematol 2016;3(2):e80-6.

26. Moorman AV, Ensor HM, Richards SM, et al. Prognostic effect of chromosomal abnormalities in childhood B-cell precursor acute lymphoblastic leukaemia: results from the UK Medical Research Council ALL97/99 randomised trial. Lancet Oncol 2010;11:429-438.

27. Moorman AV. New and emerging prognostic and predictive genetic biomarkers in B-cell precursor acute lymphoblastic leukemia.Haematologica 2016; 101(4):407-16.

28. Mann G, Attarbaschi A, Schrappe M, et al. Improved outcome with hematopoietic stem cell transplantation in a poor prognostic subgroup of infants with mixed-lineage-leukemia (MLL)rearranged acute lymphoblastic leukemia: results from the Interfant-99 Study. Blood 2010; 116(15): 2644-50.

29. Brown P, Kairalla J, Wang C, et al. Addition of FLT3 inhibitor Lestaurtinib to post-induction chemotherapy does not improve outcomes in MLL-rearranged infant acute lymphoblastic leukemia (All): AALL0631, A Children's Oncology Group Study. Pediatric blood \& cancer (SIOP 2016 Scientific Programme+Index) 2016; 63(Suppl S3, S5) abstract O-001.

30. Schultz KR, Carroll A, Heerema NA, et al. Long-term follow-up of imatinib in pediatric Philadelphia chromosome-positive acute lymphoblastic leukemia: Children‘s Oncology Group study AALL0031.Leukemia 2014; 28(7):1467-71.

31. Cazzaniga G, De Lorenzo P, Alten J, et al. Predictive value of MRD in $\mathrm{Ph}+$ 
ALL treated with imatinib in the EsPhALL study, based on IG/TR and BCR/ABL1 methodologies. Haematologica 2017; 103(1).

32. Holmfeldt L, Wei L, Diaz-Flores E, et al. The genomic landscape of hypodiploid acute lymphoblastic leukemia. Nat Genet 2013;45:242-252.

33. Mullighan CG, Jeha S, Pei D, et al. Outcome of children with hypodiploid ALL treated with risk-directed therapy based on MRD levels. Blood 2015; 126(26): 2896-9.

34. Jeha S, Pei D, Raimondi SC, et al. Increased risk for CNS relapse in pre-B cell leukemia with the $\mathrm{t}(1 ; 19) / \mathrm{TCF} 3$ PBX1. Leukemia 2009; 23(8):1406-9.

35. Tasian SK, Hunger SP. Genomic characterization of paediatric acute lymphoblastic leukaemia: an opportunity for precision medicine therapeutics. Br J Haematol 2017; 176: 867-82.

36. Moorman AV, Robinson H, Schwab $\mathrm{C}$, et al. Risk-directed treatment intensification significantly reduces the risk of relapse among children and adolescents with acute lymphoblastic leukemia and intrachromosomal amplification of chromosome 21: a comparison of the MRC ALL97/99 and UKALL2003 trials. J Clin Oncol 2013; 31(27):3389-96.

37. Harrison CJ, Moorman AV, Schwab $\mathrm{C}$, et al. An international study of intrachromosomal amplification of chromosome 21 (iAMP21): cytogenetic characterization and outcome. Leukemia 2014; 28(5):1015-21.

38. Roberts KG, Pei D, Campana D, et al. Outcomes of children with BCRABL1-like acute lymphoblastic leukemia treated with risk-directed therapy based on the levels of mini- mal residual disease. J Clin Oncol 2014;32:3012-3020.

39. Roberts KG, Li Y, Payne-Turner D, et al. Targetable kinase-activating lesions in Ph-like acute lymphoblastic leukemia. N Engl J Med 2014; 371(11): 1005-15.

40. Harvey RC, Mullighan CG, Chen IM, et al. Rearrangement of CRLF2 is associated with mutation of JAK kinases, alteration of IKZF1, Hispanic/Latino ethnicity, and a poor outcome in pediatric B-progenitor acute lymphoblastic leukemia. Blood. 2010;115:5312-5321.

41. Cario G, Zimmermann M, Romey R, et al. Presence of the P2RY8-CRLF2 rearrangement is associated with a poor prognosis in non-high-risk precursor B-cell acute lymphoblastic leukemia in children treated according to the ALL-BFM 2000 protocol. Blood 2010;115:5393-5397.

42. Riehm H, Reiter A, Schrappe M, et al. Corticosteroid-dependent reduction of leukocyte count in blood as a prognostic factor in acute lymphoblastic leukemia in childhood (therapy study ALL-BFM 83)] Klin Padiatr 1987;199(3):151-60.

43. Steinherz PG, Gaynon PS, Breneman JC, et al. Cytoreduction and prognosis in acute lymphoblastic leukemia - the importance of early marrow response: report from the Childrens Cancer Group. J Clin Oncol 1996;14(2):389-98.

44. Schrappe M, Reiter A, Zimmermann $\mathrm{M}$, et al. Long-term results offour consecutive trialsin childhood ALL performedby the ALL-BFM study group from1981 to 1995. BerlinFrankfurt-Münster. Leukemia 2000;14(12):2205-22.

45. Lauten M, Möricke A, Beier R, Zim- 
mermann M, Stanulla M, Meissner B, et al. Prediction of outcome by early bone marrow response in childhood acute lymphoblastic leukemia treated in the ALL-BFM 95 trial: differential effects in precursor B-cell and T-cellleukemia. Haematologica 2012;97(7):1048-1056.

46. StaryJ, Zimmermann M, Campbell $\mathrm{M}$, et al. Intensive Chemotherapy for Childhood Acute Lymphoblastic Leukemia: Results of the Randomized Intercontinental Trial ALL IC-BFM 2002. J Clin Oncol 2014; 32(3):174-184.

47. Schrappe M, Hunger SP, Pui CH, et al. Outcomes after induction failure in childhood acute lymphoblastic leukemia. N Engl J Med 2012;366(15):1371-1381.

48. Oudot C, Auclerc MF, Vincent Levy $\mathrm{V}$, et al. Prognostic factors for leukemic induction failure in children with acute lymphoblastic leukemia and outcome after salvage therapy: the FRALLE 93 study. J Clin Oncol 2008;26(9):1496-503.

49. Möricke A, Reiter A, Zimmermann $\mathrm{M}$, et al. Risk-adjusted therapy of acute lymphoblastic leukemia can decrease treatment burden and improve survival: treatment results of 2169 unselected pediatric and adolescent patients enrolled in the trial ALL-BFM 95. Blood 2008; 111: 4477-4489.

50. Coustan-Smith E, Behm FG, Sanchez $\mathrm{J}$, et al. Immunological detection of minimal residual disease in children with acute lymphoblastic leukaemia. Lancet 1998;351(9102):550-4.

51. Coustan-Smith E, Sancho J, Behm FG, et al. Prognostic importance of measuring early clearance of leukemic cells by flow cytometry in child- hood acute lymphoblastic leukemia. Blood 2002;100(1):52-58.

52. Dworzak MN, Fröschl G, Printz D, et al. Prognostic significance and modalities of flow cytometric minimal residual disease detection in childhood acute lymphoblastic leukemia. Blood 2002;99(6):1952-1958.

53. Borowitz MJ, Devidas M, Hunger SP, et al. Clinical significance of minimal residual disease in childhood acute lymphoblastic leukemia and its relationship to other prognostic factors: a Children's Oncology Group study. Blood 2008;111(12):5477-5485.

54. Yeoh AE, Ariffin H, Chai EL, et al. Minimal residual disease-guided treatment deintensification for children with acute lymphoblastic leukemia: results from the Malaysia-Singapore acute lymphoblastic leukemia 2003 study. J Clin Oncol 2012;30(19):2384-92.

55. Schrappe M, Valsecchi MG, Bartram CR, et al. Late MRD response determines relapse risk overall and in subsets of childhood T-cell ALL: results of the AIEOP-BFM-ALL 2000 study. Blood 2011;118(8):2077-84.

56. Vora A, Goulden N, Wade R, et al. Treatment reduction for children and young adults with low-risk acute lymphoblastic leukaemia defined by minimal residual disease (UKALL 2003): a randomised controlled trial. Lancet Oncol 2013;14(3):199-209.

57. Bader P, Kreyenberg H, Henze GHR, et al. Prognostic value of minimal residual disease quantification before allogeneic stem-cell transplantation in relapsed childhood acute lymphoblastic leukemia: the ALLREZ BFM study group. J Clin Oncol 2009;27:377-84. 
58. Brüggemann $\mathrm{M}$, Gökbuget $\mathrm{N}$ and Kneba M. Acute lymphoblastic leukemia: monitoring minimal residual disease as a therapeutic principle. Semin Oncol 2012;39(1):47-57.

59. Basso G, Veltroni M, Valsecchi MG, et al. Risk of relapse of childhood acute lymphoblastic leukemia is predicted by flow cytometric measurement of residual disease on day 15 bone marrow.J Clin Oncol 2009; 27(31):5168-74.

60. Sutton R, Venn NC, Tolisano J, et al. Australian and New Zealand Children's Oncology Group. Clinical significance of minimal residual disease at day 15 and at the end of therapy in childhood acute lymphoblastic leukaemia. Br J Haematol 2009;146:292-299. 